\title{
APPLICATION OF SALVIA OFFICINALIS AND PICEA ABIES ESSENTIAL OILS FOR CONTROLLING COLLETOTRICHUM SPP.
}

\begin{abstract}
Armina MORKELIŪNĖ, Institute of Horticulture, Lithuania Research Centre for Agriculture and Forestry, Address: Kaunas st. 30, Babtai, Kaunas dist. Lithuania; armina.morkeliune@lammc.lt

Neringa RASIUKEVČIIUTĖ, Institute of Horticulture, Lithuania Research Centre for Agriculture and Forestry, Address: Kaunas st. 30, Babtai, Kaunas dist. Lithuania; neringa.rasiukeviciute@lammc.lt (corresponding author)

Daiva BUROKIENĖ, Institute of Botany, Nature Research Centre, Adress: Žaliujų Ežerų Str. 49, Vilnius, Lithuania; daiva.burokiene@gamtc.lt

AIma VALIUŠKAITE், Institute of Horticulture, Lithuania Research Centre for Agriculture and Forestry, Address: Kaunas st. 30, Babtai, Kaunas dist. Lithuania; alma.valiuskaite@lammc.lt

Colletotrichum spp. is a significant strawberry fruit pathogen, causing yield losses of up to $80 \%$ - growing resistance to pesticides demands to new, environmentally-friendly plant protection. Essential oils (EO) are one of the biological plant protection products suitable for pathogens control. The antimicrobial and antifungal activity of EO, biodegradability and low toxicity, make it potential for use in plant protection against pathogens instead of chemical pesticides. The present study was carried out to investigate the antifungal effects of Salvia officinalis and Picea abies essential oils against strawberry Colletotrichum spp. isolate. The research carried out at the LAMMC Institute of Horticulture. The biofungicidal effect was assessed based on radial growth inhibitions. There were evaluated several EO concentrations from 1000 till 1800 $\mu 1 / 1$. Single-spore isolate fragment placed in the centre of PDA with different concentrations. Plates were incubated at $25^{\circ} \mathrm{C}$ in dark and evaluated after 2, 4, 7 days. S. officinalis and P. abies EO showed inhibitory effect on Colletotrichum spp. mycelial development. The S. officinalis inhibitory effect was more than $50 \%$ in all concentrations. The present study revealed that highest $1800 \mu \mathrm{l} / 1 \mathrm{~S}$. officinalis EO concentration Colletotrichum spp. colony diameter was significantly lower $(1.84 \mathrm{~cm})$ compared with control $(5.75 \mathrm{~cm})$. However, P. abies inhibition more than 50 $\%$ were only in concentrations from $1600 \mu \mathrm{l} / \mathrm{l}$. According to our results, treatment with EO can reduce the growth of Colletotrichum spp. and EO could be an effective potential bio-fungicide to control strawberry anthracnose. EO as bio-fungicides characteristics is their natural origin and low risk for resistance development.
\end{abstract}

Keywords: anthracnose, antifungal activity, essential oils, radial growth, inhibition.

\section{INTRODUCTION}

Growing demand for food-crops increases crop production intensity. Intensive agriculture based on large consumption of chemical pesticides and fertilisers. However, it affects negatively the natural ecosystem species diversity, contaminates groundwater and induces soil quality degradation (Scotti et al., 2015). Food contamination and plant diseases are related because most of the plants are affected by pathogens in the field. Despite that control of plant diseases reduce food contamination (Fung et al., 2018). Fungal and bacterial pathogens may occur during all plant vegetation season (planting, harvesting, postharvest) (Kwon et al., 2001). The fruits contamination by pathogens reduce their selflife. Strawberry anthracnose caused by Colletotrichum spp. can infect up to $80 \%$ of nurseries plants and cause their death and reduce yield over 50\% (Sreenivasaprasad and Talhinhas, 2005).

In agriculture are used significant amounts of pesticides for plant pathogens and insect's management all over the world. Recent studies showed that chemical pesticides have quite high side-effects, like affecting flora and fauna, water, soil and even air, besides cause resistance (Damos et al., 2015; Beckerman et al., 2015). Traditionally strawberry diseases management is based on chemical control. However, due high cost of pesticides and adverse environmental effects, it is essential to find new solutions (Rasiukevičiūtė et a., 2015; Valiuškaitè et al., 2017). In addition, natural and environmentally friendly products are investigated. The alternative plant protection means to extend shelf-life of strawberries are explored. Light-emitting diodes together with photoactive compound a perspective in the reduction of postharvest strawberry contamination (Rasiukevičiūte et al., 2015). It's essential to develop environment-friendly plant protection products that could control plant diseases. Microbiological and natural plant products obtained from plants could effectively control plant pathogens and are environment-friendly. It's been reported by several researchers that plant extracts reduce plant diseases (Šernaitè, 2017; Köhl et al., 2017). Essential oils are one of the natural plant protection products suitable for plant pathogens control. Plants contain high amount of various organic compounds. The antimicrobial and antifungal activity of essential oils and plant extracts, biodegradability and low toxicity, make it potential for use in plant protection against pathogens instead of chemicals. In addition, they are environment-friendly and wider accepted by consumers. Plant extracts and essential oils are promising products of a natural compound for the development of bio-fungicides (Antunes and Cavaco, 2010; Šernaite, 2017).

Copyright (C) 2019 The Authors. Published by Vytautas Magnus University. This is an open-access article distributed under the terms of the Creative Commons Attribution License (CC BY 4.0), which permits unrestricted use, distribution, and reproduction in any medium, provided the original author and source are credited. 
Despite adverse effect on chemical pesticides used for plant disease control and growing interest in integrated and alternative plant protection researchers are involved to find environment friendly plant protection (Rasiukevičiūte et al., 2015; Minova et al., 2015; Acimovic et al., 2016; Desam et al., 2017; Yilar et al., 2018). The Colletotrichum spp. could be inhibited by Coriandrum sativum essential oil (Acimovic et al., 2016). The Mentha piperita EO has an antimicrobial effect on Alternaria spp. and Fusarium spp. (Desam et al., 2017). The antifungal activity of plant phenolic compounds could destroy fungal cells (Freiesleben and Jager, 2014). Lamiaceae family plants such as Salvia officinalis are rich in terpenoid compounds, essential oils, flavonoids, phenolic compounds. It's been reported that Salvia species has antibacterial, antifungal and antimicrobial effect (Yilar et al., 2018). Research on antifungal activity of pine and spruce essential oils and extracts against Fusarium spp., Heterobasidion spp., Penicillium funiculum, Colletotrichum acutatum, Botrytis cinerea and other pathogens available (Minova et al., 2015).

In this paper, we have used two essential oils, as potential bio-fungicides from Salvia officinalis and Picea abies. The aim of the present study was to evaluate the antifungal effect of Salvia officinalis and Picea abies essential oils against strawberry Colletotrichum spp.

\section{MATERIALS AND METHODS}

The experiments carried out at the LAMMC Institute of Horticulture at the Laboratory of Plant Protection in Lithuania, in 2018-2019. Essential oil (EO) of dried Salvia officinalis leaves were extracted by hydro-distillation in a Clevenger-type system by 2 hours (AOAC, 1990). The EO of Picea abies leaf were obtained (UAB Naujoji Barmune).

To evaluate the effectiveness of $P$. abies and $S$. officinalis EO on Colletotrichum spp. different concentrations of EO evaluated. The essential oils were mixed separately with cooled at $45^{\circ} \mathrm{C}$ temperature potato dextrose agar (PDA) in concentrations from $1000 \mu \mathrm{l} / 1,1200 \mu \mathrm{l} / 1,1400 \mu \mathrm{l} / \mathrm{l}, 1600 \mu \mathrm{l} / \mathrm{l}$ up to $1800 \mu \mathrm{l} / \mathrm{l}$. Each concentration homogenised with PDA and distributed in Petri dishes. The isolate ( $10 \mathrm{~mm}$ diameter) of Colletotrichum spp. placed in the centre of PDA with different EO concentrations. The single spore isolates from Colletotrichum spp. infected strawberry obtained from LAMMC IH Laboratory of plant protection isolate collection. There were four replicates of individual plates per treatment. The mycelium of 7-day old fungus was put the mycelia side in the centre of Petri. Plates were incubated at 25 $\pm 2{ }^{\circ} \mathrm{C}{ }^{\circ} \mathrm{C}$ in dark. The diameter $(\mathrm{cm})$ of Colletotrichum spp. width of the disc was measured after 2,4 and 7 days after inoculation (DAI). To determine the recovery of the isolates after 7 DAI done reinoculations and growth measured after $48 \mathrm{~h}$. The percentage of mycelial growth inhibition calculated according to the formula by Ouoba et al. (2018). The data were analysed with ANOVA of SAS Enterprise Guide 7.1 program (SAS Inc., USA). The Duncan's Multiple Range Test used to determine differences among treatments.

\section{RESEARCH RESULTS}

The present study was designed to evaluate in vitro antifungal activity of Salvia officinalis, and Picea abies essential oils against Colletotrichum spp. growth. The results of $P$. abies EO at 4, 7 DAI and reinoculation are presented in Figure 1. P. abies EO inhibition more than $50 \%$ were in concentrations $1800 \mu \mathrm{l} / 12 \mathrm{DAI}$ and from $1600 \mu \mathrm{l} / 17 \mathrm{DAI}$. In addition, Colletotrichum spp. colony diameter at $1000 \mu \mathrm{l} / 1$ P. abies EO was lower $(1.69 \mathrm{~cm} /$ day $)$ compared with control $(2.96 \mathrm{~cm} /$ day $) 4 \mathrm{DAI}$. The growth in $1000 \mu \mathrm{l} / \mathrm{l}$ concentration $4 \mathrm{DAI}$ were $1.69 \mathrm{~cm} /$ day, $1200 \mu \mathrm{l} / 1-1.50 \mathrm{~cm} / \mathrm{day}, 1400 \mu \mathrm{l} / \mathrm{l}$ $-1.68 \mathrm{~cm} /$ day, $1600 \mu \mathrm{l} / \mathrm{l}-1.55 \mathrm{~cm} /$ day, $1800 \mu \mathrm{l} / \mathrm{l}-1.65 \mathrm{~cm} /$ day and in control $2.96 \mathrm{~cm} /$ day. It was still reduced by $43-$ $49 \%$ compared to control. The 7 DAI data show that the highest inhibition was at $1600 \mu 1 / 1(53.70 \%)$ and $1800 \mu \mathrm{l} / 1$ $(52.61 \%)$ concentrations. The results 7 DAI show that concentrations at $1000 \mu \mathrm{l} / 1(3.04 \mathrm{~cm} / \mathrm{day}), 1200 \mu \mathrm{l} / 1(3.00 \mathrm{~cm} / \mathrm{day})$, $1400 \mu \mathrm{l} / 1(2.98 \mathrm{~cm} /$ day $), 1600 \mu \mathrm{l} / 1(2.66 \mathrm{~cm} /$ day $)$ and $1800 \mu \mathrm{l} / 1(2.73 \mathrm{~cm} /$ day $)$ had an effect on pathogen growth compared with control $(5.75 \mathrm{~cm} /$ day). Reinoculation data present fungal recovery after the treatment with EO. The data revealed that the lowest growth of Colletotrichum spp. was in 1000-1200 $\mu \mathrm{l} / \mathrm{l}$ concentrations compared with control. Besides slight lower in 1400-1800 $\mu \mathrm{l} / \mathrm{l}$ concentrations compared with control.

It has been observed that the S. officinalis EO inhibitory effect was more than $50 \%$ in all concentrations. The results of $S$. officinalis at 4, 7 DAI and reinoculation are presented in Figure 2. After 2 DAI the mycelium diameters in $S$. officinalis were $100 \%$ suppressed in $1000 \mu \mathrm{l} / \mathrm{l}$ and $1400-1800 \mu \mathrm{l} / \mathrm{l}$ concentrations. The results demonstrated that Colletotrichum spp. at $1200 \mu \mathrm{l} / \mathrm{l}$ concentration were suppressed by $86.2 \% 2$ DAI. The $1800 \mu \mathrm{l} / \mathrm{l}$ concentration showed the highest $(87.3 \%)$ inhibition to Colletotrichum spp. growth after 4 DAI (Fig. 2). The growth in $1000 \mu 1 / 1$ concentration 4 DAI were $1.18 \mathrm{~cm} /$ day, $1200 \mu \mathrm{l} / \mathrm{l}-1.30 \mathrm{~cm} /$ day, $1400 \mu \mathrm{l} / \mathrm{l}-1.16 \mathrm{~cm} /$ day, $1600 \mu \mathrm{l} / \mathrm{l}-0.99 \mathrm{~cm} / \mathrm{day}, 1800 \mu \mathrm{l} / 1-0.38$ $\mathrm{cm} /$ day and in control $2.96 \mathrm{~cm} /$ day. The results 7 DAI show that concentrations at $1000 \mu \mathrm{l} / 1(2.89 \mathrm{~cm} / \mathrm{day}), 1200 \mu \mathrm{l} / 1(2.53$ $\mathrm{cm} /$ day), $1400 \mu \mathrm{l} / 1(2.48 \mathrm{~cm} /$ day $), 1600 \mu \mathrm{l} / 1(2.30 \mathrm{~cm} /$ day $)$ and $1800 \mu \mathrm{l} / 1(1.84 \mathrm{~cm} /$ day $)$ had an effect on pathogen compared with control $(5.75 \mathrm{~cm} /$ day). The highest concentration of S. officinalis EO inhibited Colletotrichum spp. more than $68 \% 7$ DAI. However, in 1000-1600 $\mu \mathrm{l} / 1$ inhibition were from $49.8 \%$ up to $60.0 \%$. Results showed that in reinoculation in all concentrations, isolates recovered slower than in control. The research data showed that $S$. officinalis essential oil was more effective against Colletotrichum spp. compared with $P$. abies EO. 

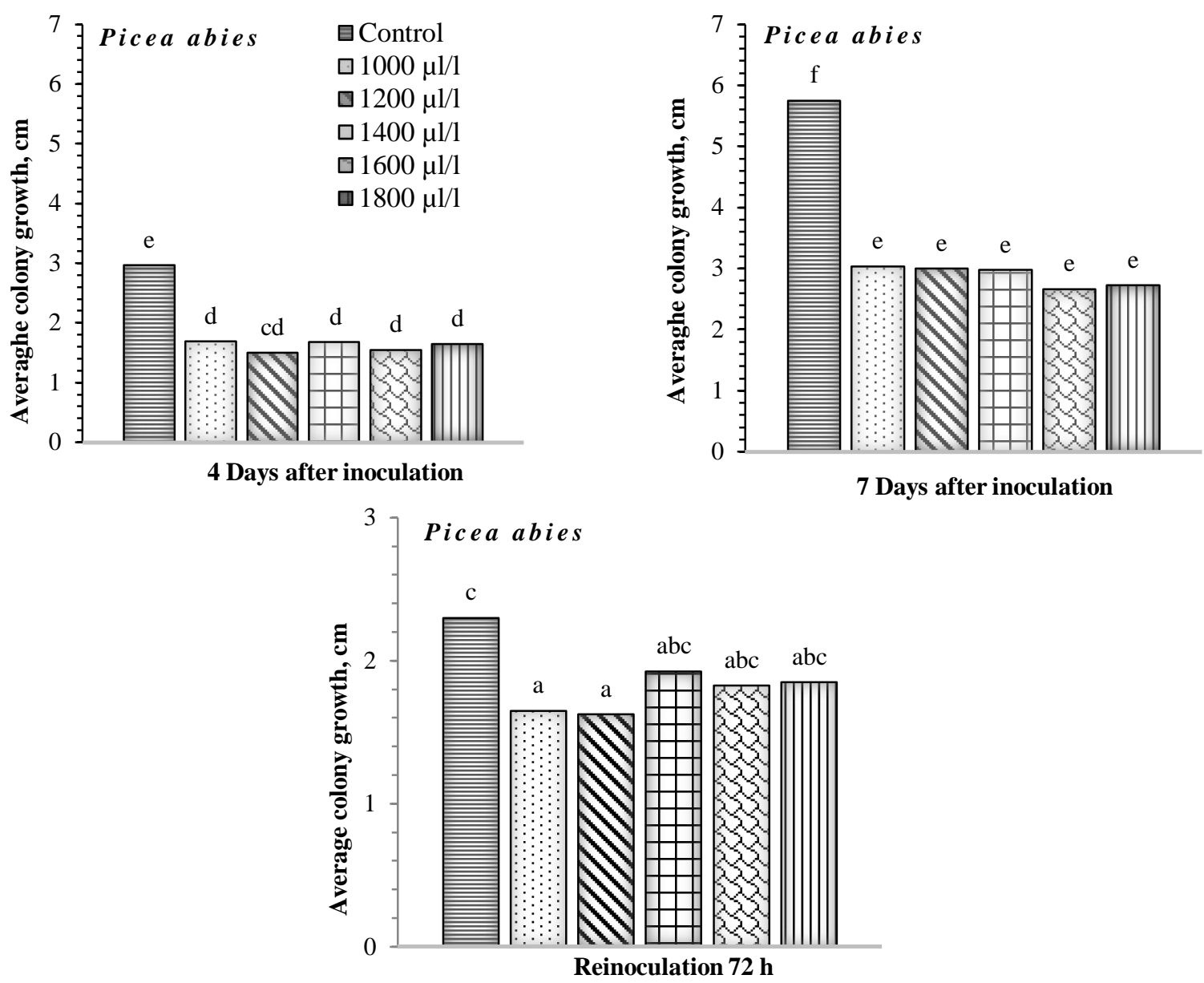

Figure 1. The antifungal effect of spruce essential oil on Colletotrichum spp. growth at different concentrations, 4 and 7 days after inoculation, and reinoculation

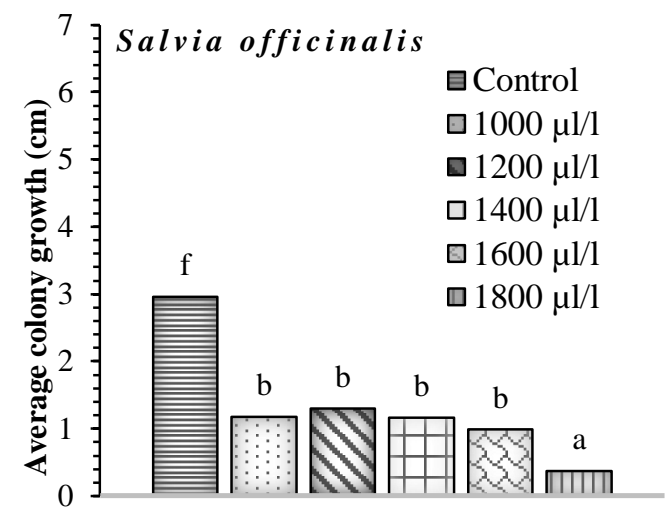

4 Days after incoulation
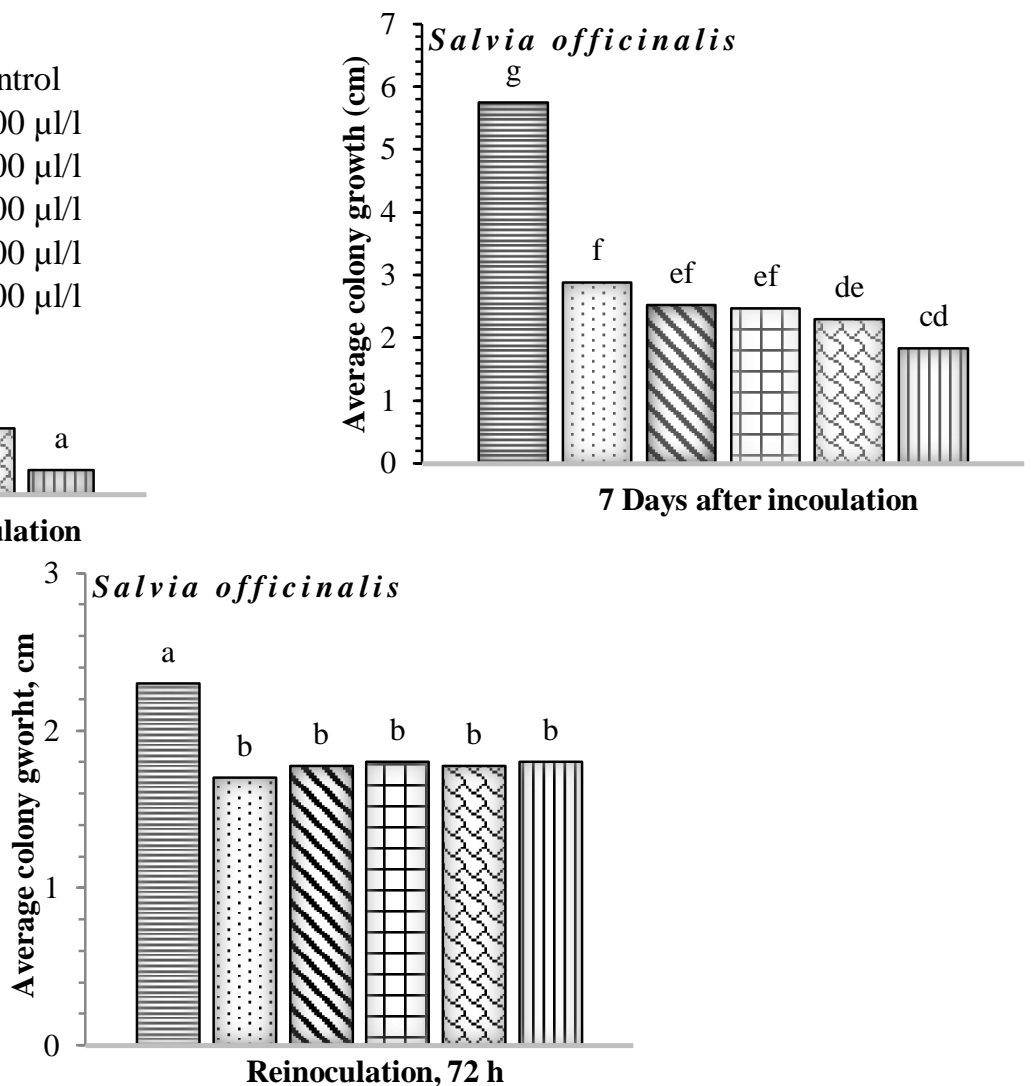

Figure 2. The antifungal effect of sage essential oil on Colletotrichum spp. growth at different concentrations, 4 and 7 days after inoculation, and reinoculation 


\section{CONCLUSIONS AND DISCUSSION}

Plant pathogens could cause significant yield losses in strawberry production (Sreenivasaprasad and Talhinhas, 2005). Therefore, controlling plant pathogens has been of great importance. The environmental problems caused by extensive use of chemical pesticides and growing resistance increased the interest of environment safer control strategies (Damos et al., 2015; Beckerman et al., 2015; Rasiukevičiūtè et a., 2015; Valiuškaitè et al., 2017). Essentials oils as biofungicides play an essential role in the plant defence mechanism against phytopathogens (Antunes and Cavaco, 2010).

In recent years, the attention on environment-friendly plant protection pays the attention of many researchers. The essential oils and plant extract demonstrate antimicrobial and antifungal activity, biodegradability and low toxicity, make it potential for use in plant protection against pathogens instead of chemicals (Minova et al., 2015; Acimovic et al., 2016; Volkova et al., 2017; Desam et al., 2017; Nikolova et al., 2017; Yilar et al., 2018). For this reason, in the present study, we have investigated the effect of essential oils from $S$. officinalis and P. abies on primary strawberry pathogen Colletotrichum spp. as promising bio-fungicides. The results from our study demonstrated that essential oils from the $S$. officinalis were more effective than $P$. abies at evaluated concentrations. However, higher concentrations could give higher inhibition. Scariot et al. (2016) noticed that $S$. officinalis essential oil has antifungal activity against Alternaria spp. and Phakopsora pachyrhizi in beans. Yilar et al. (2018) find out that Salvia tomentosa water extract inhibits mycelium growth of Botrytis cinerea $100 \%$.

In comparison, Nikolova et al. (2017) evaluated eighteen aqueous-methanolic extracts, and S. officinalis showed the highest activity against Alternaria alternata, B. cinerea and Fusarium oxysporum. There is a lack of research on $P$. abies EO against Colletotrichum spp. Comparing $20 \mathrm{~g} \mathrm{~L}^{-1}$ antifungal activity of pine and spruce bark extracts and essential oils mycelial growth inhibition of B. cinerea, C. acutatum and Phytophthora cactorum were $100 \%$ (Minova et al., 2015). Spruce biomass extract for strawberries grey mould infield was not convincing (Volkova et al., 2017). Our data shows that $P$. abies EO inhibition of Colletotrichum spp. were highest more $50 \%$ at 2 DPI in concentration $1800 \mu 1 / 1$. The EO of S. officinalis 2 DPI showed highest inhibition (100\%) at $1000 \mu \mathrm{l} / 1$ and $1400-1800 \mu \mathrm{l} / 1$ concentrations against Colletotrichum spp. However, our data indicate that that inhibition effect of EO on fungal growth varies during DPI. This data suggests that at tested concentrations we have shorter timing. Our data open perspective for environmentallyfriendly bio-fungicides from $S$. officinalis and $P$. abies EO essential oils control strawberry anthracnose. The $S$. officinalis and P. abies EO have potential to be applied as bio-fungicides against strawberry anthracnose. In addition, bio-fungicides could be a solution for solving the pesticides resistance problem.

\section{REFERENCES}

1. Acimovic M, Grahovac M, Stanković M, Masirevic S. 2016. Essential oil composition of different coriander (Coriandrum sativum L.) accessions and their influence on mycelial growth of Colletotrichum spp. Acta Scientiarum Polonorum Hortorum Cultus 15(4), pp. 35-44.

2. Antunes, M. D. C., Cavaco, A. M. 2010. The use of essential oils for postharvest decay control. A review. Flavour Fragrance Journal, Vol. 25, pp. 351-366. https://doi.org/10.1002/ffj.1986

3. Beckerman J. L., Sundin G. W., Rosenberger D. A. 2015. Do some IPM concepts contribute to the development of fungicide resistance? Lessons learned from the apple scab pathosystem in the United States. Pest Management Science, Vol. 71, pp. 331-342. https://doi.org/10.1002/ps.3715

4. Damos P., Colomar L. A., Ioriatti C. 2015. Integrated fruit production and pest management in Europe: the apple case study and how far are from the original concept? Insects, Vol. 6, Iss. 3, pp. 626-657. https://doi.org/10.3390/insects6030626

5. Desam N. R., Al-Rajab A. J., Sharma M., Mylabathula M. M., Gowkanapalli R. R., Albratty M. 2017. Chemical constituents, in vitro antibacterial and antifungal activity of MenthaxPiperita L. (peppermint) essential oils. Journal of King Saud University - Science. https://doi.org/10.1016/j.jksus.2017.07.013

6. Freisesleben S. H., Jager A. K. 2014. Correlation between plant secondary metabolites and their antifungal mechanism-a review. Medical \& Aromatical Plants, Vol. 3, pp. 1-6.

7. Fung, F., Wang, H. S., Menon, S. 2018. Food safety in the 21 st century. Biomedecial Journal, Vol. 41, pp. 88-95. https://doi.org/10.1016/j.bj.2018.03.003

8. Köhl J., Booij K., Kolnaar R., Ravensberg W. J. 2019. BioControl, Vol. 64, Iss. 5 pp. 469-487. https://doi.org/10.1007/s10526-019-09964-y

9. Kwon J-H., Kang S-W., Kim J-S Park C-S. 2001. Rhizopus soft rot on cherry tomato caused by Rhizopus stolonifer in Korea. Mycobiology, Vol. 29, Iss. 3, pp. 176-178. https://doi.org/10.1080/12298093.2001.12015783

10. Minova S., Seškena,R., Voitkane S., Metla Z., Daugavietis M., Jankevica L. 2015. Impact of pine (Pinus sylvestris L.) and spruce (Picea abies (L.) Karst.) bark extracts on important strawberry pathogens. Proceedings of the Latvian academy of sciences. Section B, Vol. 69(1/2), pp. 62-67. https://doi.org/10.1515/prolas-2015-0008

11. Nikolova M., Yordanov P., Slavov S., Berkov, S. 2017. Antifungal activity of plant extracts against phytopathogenic fungi. Journal of BioScience \& Biotechnology, Vol. 6(2), pp. 155-161.

12. Ouoba P., Ouattara L., Bonzi S., Yameogo J.T., Somda I. 2018. Evaluation of antifungal activity and phytotoxicity of the essential oil of Zanthoxylum zanthoxyloides fruits. Agricultural science research journal, Vol. 8(4), pp. 92-99.

13. Rasiukevičiūtė N., Valiuškaitė A., Uselis N., Buskienė L., Viškelis J., Lukšienė Ž. 2015. New non-chemical postharvest technologies reducing berry contamination. Žemdirbytsé-Agriculture, Vol. 102, No. 4, pp. 411-416. https://doi.org/10.13080/z-a.2015.102.052

14. Scariot M. A., Reichert Júnior F. W., Radünz L. L., Barro J. P., Mossi A.J. 2016. Salvia officinalis essential oil in bean weevil control. Pesquisa Agropecuária Tropical, Vol. 46(2), pp. 177-182. https://doi.org/10.1590/1983-40632016v4640034

15. Scotti R., Bonanomi G., Scelza R., Zoina A., Rao M. A. 2015. Organic amendments as sustainable tool to recovery fertility in intensive agricultural systems. Journal of soil science and plant nutrition, Vol. 15(2), pp. 333-352. https://doi.org/10.4067/S0718-95162015005000031

16. Šernaitė L. 2017. Plant extracts: antimicrobial and antifungal activity and appliance in plant protection (Review). Sodininkyste ir daržininkyste், No. 36 (3-4), pp. 58-68. (In Lithuanian) 
17. Sreenivasaprasad S, Talhinhas P. 2005. Genotypic and phenotypic diversity in Colletotrichum acutatum, a cosmopolitan pathogen causing anthracnose on a wide range of hosts. Molecular Plant Pathology, Vol. 6, pp. 361-378. https://doi.org/10.1111/j.1364-3703.2005.00291.x

18. Valiuškaitẻ A., Uselis N., Kviklys D., Lanauskas J., Rasiukevičiūtė N. 2017. Effect of sustainable plant protection and apple tree management on fruit quality and yield. Žemdirbytsé-Agriculture, Vol. 104, No. 4, pp. 353-358. https://doi.org/10.13080/z-a.2017.104.045

19. Volkova, J., Laugale, V., Lepse, L., Baženova, A., Jankevica, L., Daugavietis, M. 2014. Evaluation of spruce biomass extract for control of grey mould (Botrytis cinerea) in field-grown strawberries. Environmental and Experimental Biology, Vol. 12, pp. 89-93.

20. Yilar, M., Kadioglu, I., Telci, I. 2018. Chemical composition and antifungal activity of Salvia Officinalis (L.), S. Cryptantha (Montbret et aucher ex Benth.), S. Tomentosa (MILL.) plant essential oils and extracts. Fresenius Environmental Bulletin, Vol. 27, Iss. 3, pp. $1695-1706$. 